THURSDAY, SEPTEMBER 8, xوіо.

\section{ORE DEPOSITS.}

(I) The Ore Deposits of South Africa. By J. P. Johnson. Part ii., The Witwatersrand and Pilgrims' Rest Goldfields and Similar Occurrences. Pp. vi +51 . (London: Crosby Lockwood and Son, 1909.) Price $5 s$, net.

(2) The Geology of Ore Deposits. By H. H. Thomas and D. A. MacAlister. Pp. xi+4I6. (London: E. Arnold, 1909.) Price $7 s .6 d$. net.

( ) THE second part of Mr. Johnson's "Ore Deposits of South Africa," of which the first part was reviewed in Nature, June 3, 1909, vol. 1xxx., p. 395, deals with the goldfields of the Transvaal. The book is intended for the use of prospectors and students, and consists of brief descriptions of each mining field and of short discussions of the genesis of the ores. It is illustrated with sections of the mines, and outline maps of which the shading is not always clearly explained. The author gives an excellent summary of the arguments for the placer and impregnation theories of the origin of the Rand ores, and says that "judging them on their own evidence the writer would unhesitatingly class them as detrital ore deposits" (p. 17). He suspends judgment, however, from the consideration that the gold at Pilgrims' Rest is due to impregnation. The ores at Pilgrims' Rest are quartz stringers in dolomite and altered dolomite; and they are doubtless of the same origin as those in the dolomites of South Dakota, which are strikingly different in all essential characters from the banket of the Rand. Mr. Johnson's remark that the analogy between the ores of Pilgrims' Rest and of the Rand is the strongest argument in favour of the impregnation theory for the banket is not complimentary to the other arguments. The most useful parts of the book are the chapters on the lessknown secondary goldfields of the Transvaal.

(2) Messrs. Thomas and MacAlister's "Geology of Ore Deposits " agrees with Mr. Johnson's book in the conciseness with which it summarises the structures of various mining fields. It is, however, world-wide in its range. It should prove of great service as a textbook to students of economic geology who desire a clear statement of current theories. As the authors, in 416 small pages, state the principles of ore formation and explain them by reference to occurrences in nearly every mining country, the work necessarily suffers by extreme compression. There are no references to authorities, and, owing to their absence, the reader is sometimes left in doubt whether evidence opposed to the authors' conclusions has been weighed and rejected or has escaped their diligent search. An omission that might have been avoided is an index of localities. The same mining field may be referred to in different chapters, and so many mining localities are mentioned that a geographical index would have added greatly to the usefulness of the book as a work of preliminary reference. Some statistics of ore yields would also have been an advantage as showing the relative importance of the different processes of

$$
\text { NO. } 2 \text { I } 32 \text {, VOL. 84] }
$$

mineral deposition; the authors mention some insignificant ore occurrences which are of no economic importance, and some of which have not been worked, and inferences drawn from them as to the origin of the larger ore masses may be invalid. Owing to the wide range of the book it is not surprising that it contains small mistakes, both geological and geographical, in reference to foreign mining fields.

The classification of ores adopted by the authorities is based solely on genetic grounds. They describe first the ores due to the segregation of metals in igneous rocks, a process to which the authors perhaps attach undue importance, judged by the economic value of the ores thus produced. In succeeding chapters they describe ores due to pneumatolysis, to the action of heated solutions resulting from igneous intrusions, to metasomatic replacement, to metamorphism, to precipitation, and to the deposition of detritus. A special chapter describes the changes in ore deposits apart from those included under metamorphism. The authors show remarkably wide acquaintance with the literature of ore deposits and a sound and cautious judgment. They accept the detrital origin of the gold in the Rand Banket, and reject the view that nuggets are formed by deposition from solution in the drifts wherein they are found. The accounts of the British and especially of the Cornish ores are the best in the book, many of the references to the foreign fields being too brief to do more than show the place assigned to the ores in the authors' classification.

One significant and interesting feature in this book is the complete abandonment in a British text-book of that morphological classification of ores which was for so long dominant in this country that it has been described as "the British classification."

J. W. G.

OBSERVATIONAL METEOROLOGY.

Meteorology, Practical and Applied. By Sir John Moore. Second revised and enlarged edition. Pp. xxvii +492. (London: Rebman, Ltd., 1910.) Price Ios. $6 d$. net.

DURING the last fifteen years much progress has been made in the study of meteorologv, as a comparison between the first and second editions of Sir John Moore's treatise amply demonstrates. Expansion in some directions necessitating curtailment in others has changed and improved the work. As an example of addition we may instance the account of the investigation of the upper atmosphere with the information acquired of the isothermal layer and the behaviour of air currents. This inquiry, practically limited to the interval between the appearance of the two editions, has reacted, in various ways, traces of which will be found in the book. It has given a strong impulse to the work of designing accurate self-recording instruments, necessitating a considerable increase in the chapters devoted to the methods of measurement and registration of climatic factors. Through the increased attention attracted to meteorology and the firmer scientific foundation thus acquired, there has arisen the 